\title{
Low-pressure metamorphism during Archaean crustal growth: a low-strain zone in the northern Nagssugtoqidian orogen, West Greenland
}

\author{
Adam A. Garde, Mads Sylvest Christiansen, Julie A. Hollis, Stanislaw Mazur and \\ Jeroen A.M. van Gool
}

One of the first detailed accounts of Precambrian supracrustal rocks in central West Greenland came from a small group of islands and skerries a few kilometres north-east of Aasiaat (Fig. 1). In 1948, K. Ellitsgaard-Rasmussen spent a few days on the islands and published a metamorphic study of their low-grade greenstones and aluminous clastic rocks (Ellitsgaard-Rasmussen 1954). He observed a striking dissimilarity between these supracrustal rocks and the grey gneisses found in most of the Aasiaat region, although the latter were at that time also assumed to be of supracrustal origin. He furthermore noted that the regional significance of the islands should be pursued, and that the island of
Maniitsoq $4 \mathrm{~km}$ west of the small islands might hold a key to their interpretation.

More than 50 years were to elapse before the islands were surveyed again in July 2003, during field work for the Ikamiut map sheet in the northern Nagssugtoqidian orogen (van Gool et al. 2002). The collision of two Archaean continents during the $c .1850 \mathrm{Ma}$ Nagssugtoqidian orogeny caused intensive structural and thermal reworking at up to granulite facies grade in most of central West Greenland; see Connelly et al. (2000) and van Gool et al. (2002). The small islands north-east of Aasiaat are indeed regionally important, because they document a previously unrecognised low-grade,

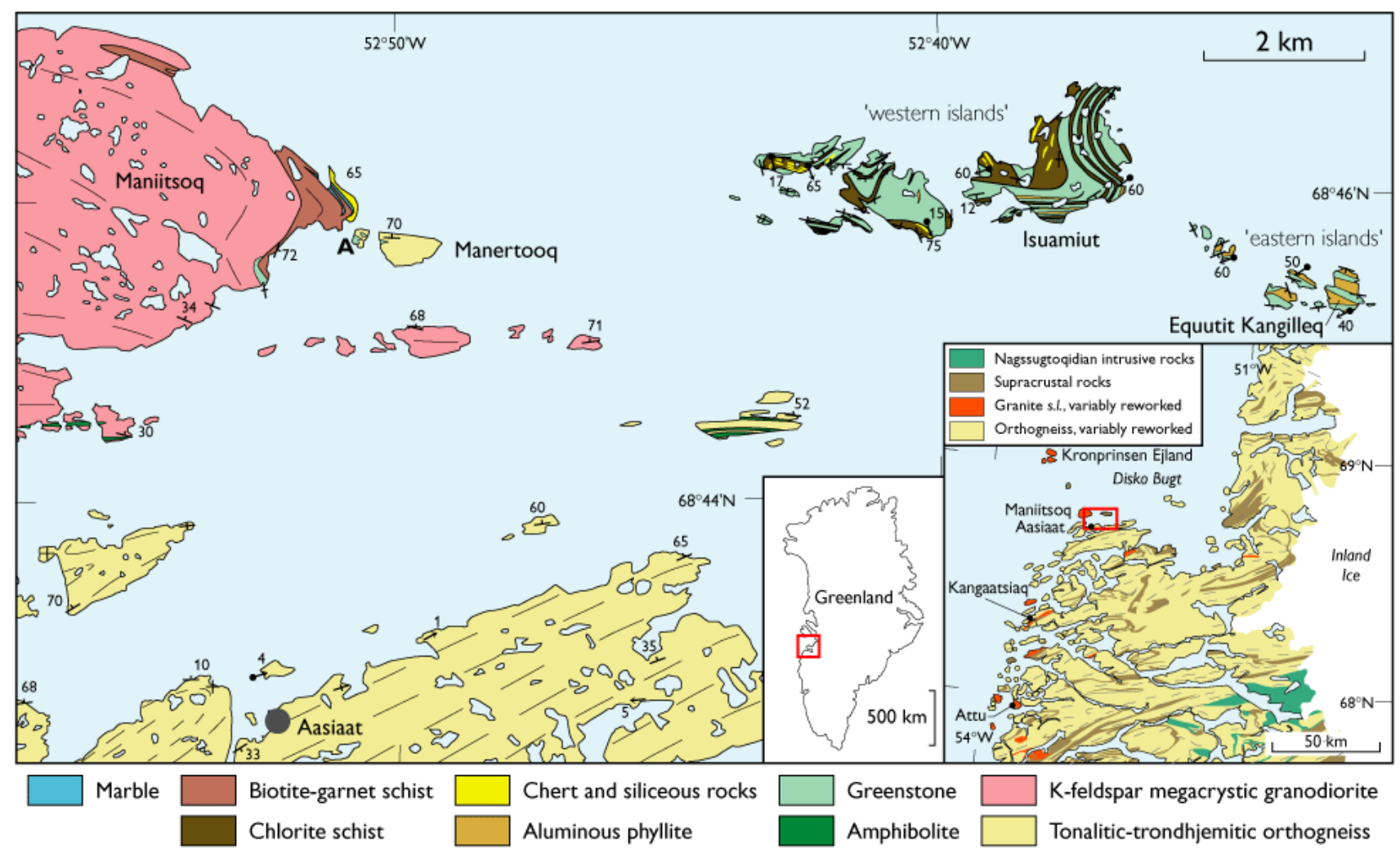

Fig. 1. Geological map of the low-grade, low-strain area north of Aasiaat. The well-preserved supracrustal rocks on the island groups around Isuamiut and Equtiit Kangilleq were originally mapped by Ellitsgaard-Rasmussen (1954). Maniitsoq and the small island west of Manertooq (A) still preserve intrusive contacts of (?) Archaean granodiorite and tonalite into the supracrustal rocks, whereas the intensity of Palaeoproterozoic (Nagssugtoqidian) strain increases greatly towards the south. The inset map shows the location of the study area in the northern part of the Nagssugtoqidian orogen. 


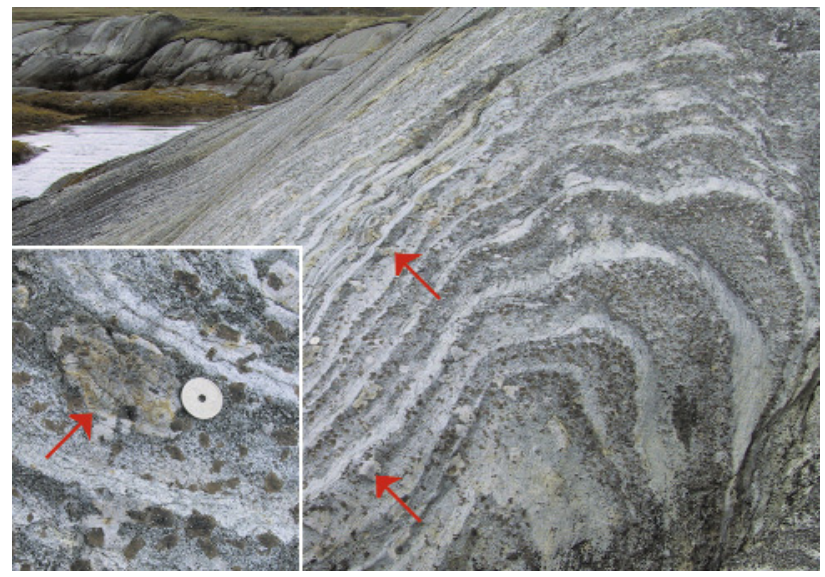

Fig. 2. Folded aluminous rocks with preserved graded bedding. Andalusite porphyroblasts up to $5 \mathrm{~cm}$ across (arrows and inset) occur in the bed tops. Scale shown by $2.8 \mathrm{~cm}$ coin left of centre. South side of small island between Isuamiut and Equutit Kangilleq.

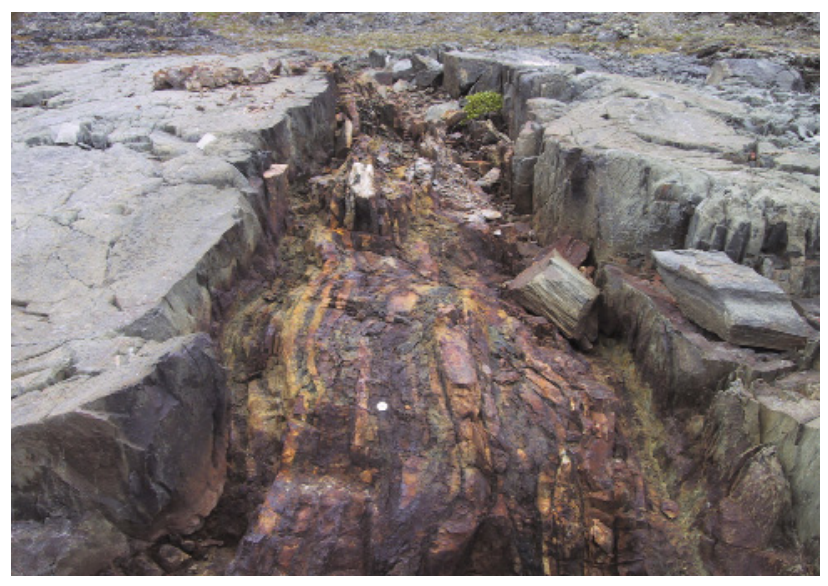

Fig. 3. Vertical layer of banded iron formation and chert, c. $1 \mathrm{~m}$ wide, within massive greenstones. Northern Isuamiut.

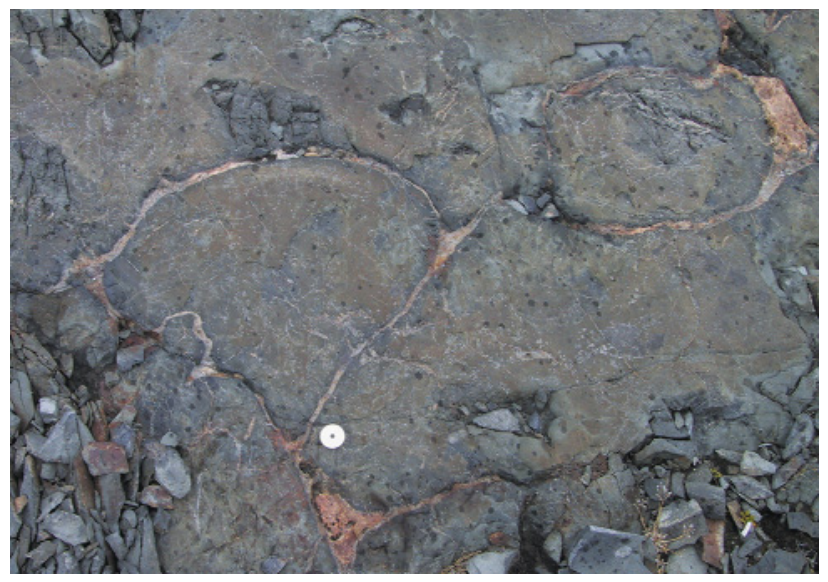

Fig. 4. Pillow lava; horizontal surface of steeply dipping unit younging north-west. Coin, $2.8 \mathrm{~cm}$ across, at cuspate pillow base for scale. Northern Isuamiut. low-strain domain of presumed Archaean age that has largely escaped the Nagssugtoqidian orogeny, and as predicted by Ellitsgaard-Rasmussen (1954) a clue to their significance was found on Maniitsoq.

\section{The low-grade supracrustal rocks}

The islands form two different groups (Fig. 1). The eastern islands, of which Equutit Kangilleq is the largest, consist of pale grey, andalusite-staurolite-muscovite-biotite-garnetquartz-bearing metasedimentary rocks interspersed with abundant fine-grained mafic sills. Graded bedding on a scale of $5-10 \mathrm{~cm}$ is commonly preserved, and up to $c .5 \mathrm{~cm}$ large, undeformed andalusite porphyroblasts are found in the aluminous bed tops (Fig. 2). Randomly orientated, centimetresized staurolite porphyroblasts are also abundant. A $1 \mathrm{~m}$ thick aluminous pegmatite with up to $15 \mathrm{~cm}$ sized, euhedral andalusite crystals and even larger masses of cordierite were also observed. Mafic sills reach thicknesses of a few tens of metres. They are generally fine-grained, massive and dark greenish in colour, and commonly display up to $10 \mathrm{~cm}$ thick garnet-bearing reaction rims along their margins. The rocks record a simple deformational history: open to tight folds with amplitudes and wavelengths in the order of $1 \mathrm{~km}$ have steeply SE- or SW-plunging axes and are associated with a steep, centimetre-spaced cleavage that overprints bedding.

The coastal exposures of the western islands (of which Isuamiut is the largest, Fig. 1) consist of dark grey, massive greenstones interspersed with smaller volumes of dark, very fine-grained chlorite schist, mixed horizons of finely layered chert and hematite-dominated, manganiferous banded iron formation (Fig. 3) and calcareous layers less than $1 \mathrm{~m}$ thick rich in actinolite. Most of the greenstones are sill complexes up to $c .1 \mathrm{~km}$ thick with common columnar jointing and locally preserved internal intrusive contacts and chilled margins. Irregular quartz and calcite veins up to $c .10 \mathrm{~cm}$ thick are very common and may have formed by cementation of open joint systems. On the north-west coast of Isuamiut a small area of well-preserved pillow lavas was also found (Fig. 4), clearly demonstrating that the basic magmatism was contemporaneous with sedimentation, in contrast to the view of Ellitsgaard-Rasmussen (1954) that the basic magmatism occurred during folding. Pillow lava cusps, asymmetric distribution of gas vesicles and graded bedding in adjacent clastic rocks, all point to north-west younging. The general style of deformation, with a simple system of steeply SW- and SEplunging open to close folds, is very similar to that on the eastern islands (Fig. 1). Steep pencil structures in fold hinges, formed by intersection between cleavage and bedding, demonstrate that the overall deformation was constrictional with subvertical extension. 
Both the eastern and western islands represent the deposits of a volcanic basin dominated by basic magmatism, with associated chemical sediments now found as chert, banded iron formation and calcareous rocks. The intercalated clastic metasedimentary rocks are very fine-grained and were thus deposited far from continental crustal sediment sources. The origin of the aluminous metasediments on the eastern islands is less clear, although they may also be pelagic sediments.

Low-grade supracrustal rocks, reminiscent of those described above, occur on Hunde Ejland and adjacent small islands about $10 \mathrm{~km}$ north-west of Maniitsoq, but were only briefly surveyed (inset map on Fig. 1). Layered basic volcanic rocks and sills are intercalated with thin horizons of finegrained chemical and clastic metasedimentary rocks in which chlorite and muscovite are the dominant phyllosilicates; the metamorphic grade appears to have been too low for growth of aluminosilicates. The deformation was sufficiently intense to develop a penetrative schistosity, and bedding-cleavage relationships are only rarely preserved in fold hinges.

\section{Relationships with the quartzo-feldspathic gneisses in the Aasiaat area}

Orthogneisses are absent from the small islands north-east of Aasiaat, and their relationships with the low-grade supracrustal association therefore cannot be studied directly. However, a more strongly deformed and higher grade continuation of the supracrustal association probably occurs along strike some $4 \mathrm{~km}$ to the west, in the easternmost part of Maniitsoq island and on a small island immediately to its east (A on Fig. 1). In this area, fine-grained amphibolite considered to be a lateral continuation of the greenstones is intruded by a characteristic unit of K-feldspar megacrystic granodiorite (on Maniitsoq), or by grey tonalite (on the small island). The intrusive contacts are weakly deformed but otherwise well preserved (Fig. 5). Most of Maniitsoq is covered by the megacrystic granodiorite, preserved in a weakly deformed state close to its original magmatic appearance; the granodiorite is cut by several sets of flat-lying and inclined pegmatites, and large angles between individual pegmatite phases are still present. A similar, likewise un-migmatised, Kfeldspar porphyritic granodiorite was also observed on Kronprinsen Ejland and may be part of the same pluton.

More deformed outcrops of the megacrystic granodiorite have been recognised on several small islands south of Maniitsoq, and further south these give way to grey tonalitic orthogneiss (Fig. 1). Both the granodiorite and orthogneiss become increasingly strongly deformed southwards, and pegmatites are tectonically thinned and lose their angular discordance (Fig. 6). Southwards, towards Aasiaat, the rocks exhibit an intense E-W-trending vertical planar fabric and subhori-

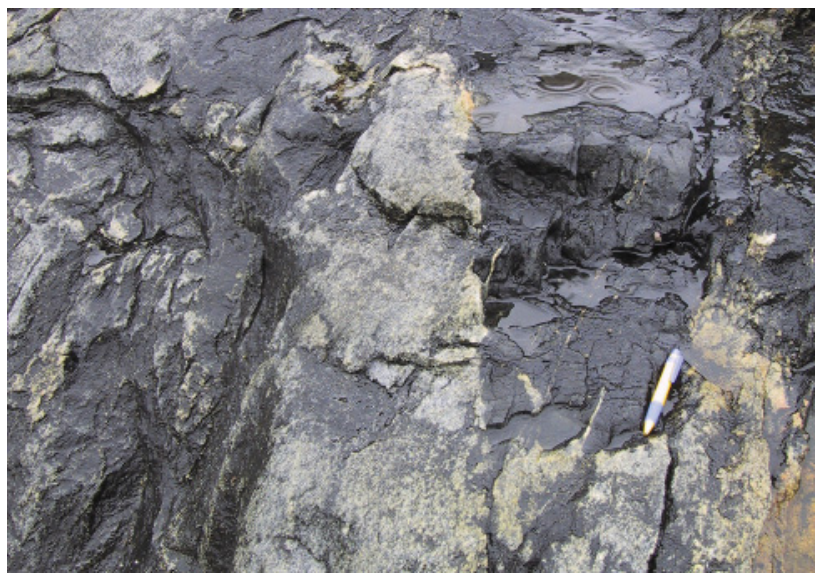

Fig. 5. Fine-grained amphibolite intruded by weakly deformed tonalite. Pen points at angular discordance. West side of island between Maniitsoq and Manertooq (A on Fig. 1).

zontal lineation related to upright, kilometre-scale, tight to isoclinal folds.

\section{Metamorphism and regional significance}

The occurrence of andalusite as the stable aluminosilicate phase in staurolite-bearing pelitic rocks is consistent with low pressure metamorphic conditions of $\leq 3 \mathrm{kbar}$. However, mineral assemblage constraints indicate significant variations in temperature, from chlorite zone greenschist facies up to midupper amphibolite facies. For example, on the western islands chlorite-graphite and garnet-chlorite schists dominate the metasedimentary assemblages; on the eastern islands staurolite-biotite rocks are common, indicating up-temperature crossing of the staurolite isograd $\left(c .520-550^{\circ} \mathrm{C}\right)$.

The regional variation in metamorphic grade, coupled with the intrusive relationships observed in the Maniitsoq area, strongly suggest metamorphism during emplacement of the granodioritic-tonalitic magmas into the upper crust. The age of emplacement of these plutons is currently unknown; based on regional age data (e.g. Connelly et al. 2000) it is presumed that the grey gneisses are late Archaean, and $\mathrm{U}-\mathrm{Pb}$ geochronology to confirm this is under way.

Both previous work in the northern Nagssugtoqidian orogen and new observations of intensely deformed Palaeoproterozoic basic dykes in the Aasiaat region itself, indicate that the intense E-W structural grain in the KangaatsiaqAasiaat region is due to the Nagssugtoqidian continent collision, although almost all of the exposed rocks are of Archaean age. Contemporaneous deformation also took place north-east of Disko Bugt, and it has recently been suggested that the Nagssugtoqidian orogeny also incorporated the Rinkian fold belt in northern West Greenland to form a com- 


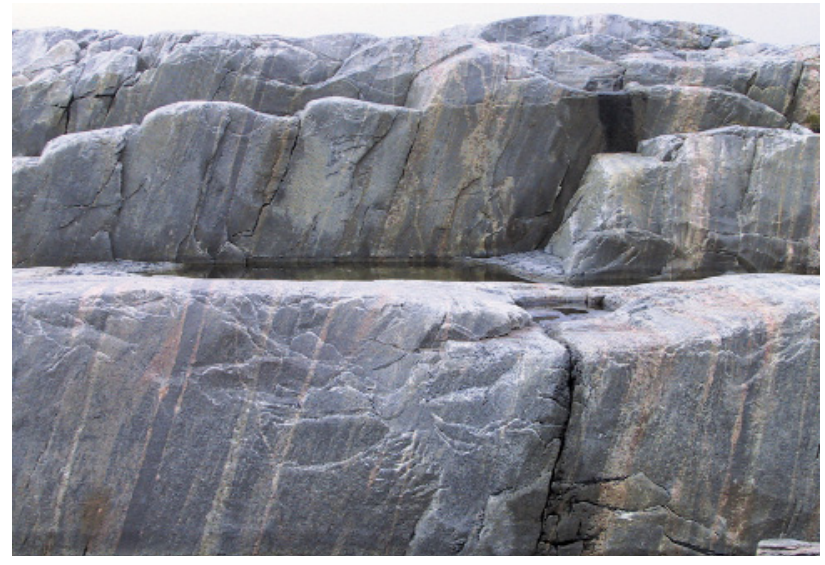

Fig. 6. Intensely deformed granodiorite with several generations of pegmatites rotated into parallelism. The exposure is c. $3 \mathrm{~m}$ high. Island $2 \mathrm{~km}$ east-south-east of Manertooq.

mon, more than $1000 \mathrm{~km}$ wide collisional belt extending from West Greenland far into eastern Canada (Thrane et al. 2003).

Other domains of low Palaeoproterozoic strain in the Nagssugtoqidian-Rinkian orogenic system have previously been described, e.g. from the area north-east of Disko Bugt (cf. Garde \& Steenfelt 1999) and between Kangaatsiaq and Attu (Piazolo et al. 2004); the former area is generally assumed to consist of a tectonic block that was downthrown along a major extensional shear zone (Garde \& Steenfelt 1999). At Aasiaat, however, the strain increase is gradual, taking place over a width of several kilometres. Furthermore, the intense subhorizontal lineation in the Aasiaat area is perpendicular to the N-S direction of increased strain; it therefore indicates that the main tectonic transport was lateral and did not include a significant vertical component.

\section{Conclusions}

Greenstones and aluminous metasediments of presumed Archaean age crop out on a few small islands north of Aasiaat and have been excellently preserved in a low-temperature and low-strain window in the northern part of the Nagssugtoqidian orogen in West Greenland. These relatively lowgrade rocks may well represent the oldest component of the region, recording a history of metamorphism and deformation during Archaean crustal growth. They provide a unique opportunity to study the primary lithological components of the Archaean supracrustal belts that are intercalated with the regional grey gneisses. In addition, the state of preservation of the supracrustal rocks provides support for an inhomogeneous Nagssugtoqidian orogenic overprint, where blocks with intense thermal and tectonic reworking seem to alternate with blocks of only weak reworking.

Based on hornblende Ar-Ar cooling ages, Willigers et al. (2002) proposed that the Nagssugtoqidian orogeny resulted in uniform heating in most of the orogen (including its northern part), followed by very slow cooling during isostatic uplift. The preliminary observations reported here appear to contradict this, but more work is required to substantiate the new findings.

\section{Acknowledgements}

The authors thank Christian Knudsen, Mac Persson, Sandra Piazolo and Thomas Rasmussen for their contributions to the study of the Aasiaat region.

\section{References}

Connelly, J.N., van Gool, J.A.M. \& Mengel, F.C. 2000: Temporal evolution of a deeply eroded orogen: the Nagssugtoqidian orogen, West Greenland. Canadian Journal of Earth Science 37, 1121-1142.

Ellitsgaard-Rasmussen, K. 1954: On the geology of a metamorphic complex in West Greenland. The islands of Anarssuit, Isuamiut, and Eqûtit. Bulletin Grønlands Geologiske Undersøgelse 5, 70 pp.

Garde, A.A. \& Steenfelt, A. 1999: Precambrian geology of Nuussuaq and the area north-east of Disko Bugt. In: Kalsbeek, F. (ed.): Precambrian geology of the Disko Bugt region, West Greenland. Geology of Greenland Survey Bulletin 181, 6-40.

Piazolo, S., Alsop, G.I., Nielsen, B.M. \& van Gool, J.A.M. 2004: The application of GIS to unravel patterns of deformation in high grade terrains: a case study of indentor tectonics from West Greenland. In: Alsop, G.I \& Holdsworth, R.E. (eds): Flow processes in faults and shear zones. Geological Society Special Publication (London) 224, 63-78.

Thrane, K., Connelly, J., Garde, A.A. Grocott, J. \& Krawiec, A.W. 2003: Linking the Palaeoproterozoic Rinkian and Nagssugtoqidian belts of central West Greenland: implications of new U-Pb and $\mathrm{Pb}-\mathrm{Pb}$ zircon ages. Geophysical Research Abstracts 5(09275).

van Gool, J.A.M., Connelly, J.N., Marker, M. \& Mengel, F.C. 2002: The Nagssugtoqidian Orogen of West Greenland: tectonic evolution and regional correlations from a West Greenland perspective. Canadian Journal of Earth Science 39, 665-686.

Willigers, B.J.A., van Gool, J.A.M., Wijbrans, J.R., Krogstad, E.J. \& Mezger, K. 2002: Post-tectonic cooling of the Nagssugtoqidian orogen and a comparison of contrasting cooling histories in Precambrian and Phanerozoic orogens. Journal of Geology 110, 503-517.

\section{Authors' addresses}

A.A.G., M.S.C., J.A.H. \& J.A.M.v.G., Geological Survey of Denmark and Greenland, Øster Voldgade 10, DK-1350 Copenhagen K, Denmark. E-mail: aag@geus.dk

S.M., Institute of Geological Sciences, University of Wroclaw, Pl. Maxa Borna 9, 50-204 Wroclaw, Poland. 